\title{
Chemical characterization of agroforestry solid residues aiming its utilization as adsorbents for metals in water
}

Francisco H. M. Luzardo ${ }^{1}$, Fermin G. Velasco ${ }^{2}$, Clemildes P. Alves ${ }^{3}$, Ivea K. da S. Correia ${ }^{4}$ \& Lázaro L. Cazorla ${ }^{5}$

\section{Key words:}

vegetable residues

metal adsorption

chemical functional groups

adsorbent

\begin{abstract}
A B S T R A C T
In this work, a study of the correlation between the functional groups present in the chemical structure of the fibers of coconut shells, cocoa and eucalyptus, and their adsorption capacity of $\mathrm{Cd}^{+2}$ and $\mathrm{Cu}^{+2}$ ions from water was performed. The content of soluble solids and reactive phenols in aqueous extracts were determined. The chemical functional groups present in the fibers were examined using the IR spectra. The adsorption capacity of the peels was determined using atomic absorption spectrophotometer. For $\mathrm{Cd}^{+2}$, a significant correlation between the adsorption capacity and some specific chemical functional groups present in the fiber was verified. The potential use of these peels, as adsorbent of $\mathrm{Cd}^{+2}$ ions, is based on the presence of $\mathrm{OH}$ functional groups such as aryl-OH, aryl-O- $\mathrm{CH}_{2}$ of phenol carboxylic acids, as well as carbonyl groups derived from carboxylic acid salts, in these fibers.
\end{abstract}

\section{Palavras-chave:}

resíduos vegetais adsorção de metais grupos funcionais químicos adsorvente

\section{Caracterização química de resíduos sólidos agroflorestais visando à sua utilização como adsorventes de metais em água}

\section{R E S U M O}

Neste trabalho foi realizado um estudo da correlação entre os grupos funcionais presentes na estrutura química das fibras de casca de coco, cacau e de eucalipto e sua capacidade de adsorção de íons de $\mathrm{Cd}^{+2}$ e $\mathrm{Cu}^{+2}$ da água. Foram determinados o teor de sólidos solúveis e fenois reativos em extratos aquosos. Os grupos químicos funcionais presentes nas fibras foram analisados utilizando-se os espectros de IV. A capacidade de adsorção das cascas foi determinada através de um espectrofotômetro de absorção atômica. Para os íons de $\mathrm{Cd}^{+2}$ foi encontrada uma correlação significativa entre a capacidade de adsorção e alguns grupos funcionais químicos presentes na fibra. $\mathrm{O}$ uso potencial dessas cascas, como adsorvente de íons de $\mathrm{Cd}^{+2}$, se baseia na presença de grupos funcionais arilo- $\mathrm{OH}$, arilo- $\mathrm{O}-\mathrm{CH}_{2}$ de ácidos carboxílicos fenois, tais como grupos carbonila derivados a partir de sais de ácidos carboxílicos, nessas fibras.

Protocolo 392.13 - 10/12/2013 • Aprovado em 08/08/2014 • Publicado em 01/01/2015

${ }^{1}$ DCET/UESC. Ilhéus, BA. E-mail: fmartinezluzardo@gmail.com (Autor correspondente)

${ }^{2}$ DCET/UESC. Ilhéus, BA. E-mail: fermingv@gmail.com

${ }^{3}$ DCET/UESC. Ilhéus, BA. E-mail: cpalves@uesc.br

${ }^{4}$ PRODEMA/UESC. Ilhéus, BA.E-mail: ivea.correia@gmail.com

${ }^{5}$ Instituto Superior de Tecnologiass y Ciencias Aplicadas, La Habana, Cuba. E-mail: laz.yas.kev@gmail.com 


\section{INTRODUCTION}

The search for more effective and cheaper materials capable of removing toxic metals from industrial effluents is a very important task for the sustainable development. The trading adsorbents produced in the developed countries are marketed with exorbitant price to the majority of the world's population and they remain with several technical issues still open. From the agricultural and forestry production come huge quantities of residues, which have been the subjects of researches about their adsorption capacity of metal ions. These residues can be used individually for removing toxic metals from waters. For this purpose, it is necessary to characterize these residues for their use as adsorbents according to the source of contamination.

Residues from different agricultural and forestry activities usually present several similar physical and chemical characteristics. They are fibrous materials capable of accumulating varying degrees of moisture. Their structure is composed by cellulose, hemicellulose, lignin, pectin, starch, among others. In addition to these substances, other organic and inorganic ones, predominantly phenolic compounds and polyphenols, may be present in their composition. In most of these residues, substances, with different chemical functional groups that are able to combine themselves with metal ions, are found.

Some review papers extensively reported this issue (Bailey et al., 1999; Mohan \& Pittman, 2007; Sud et al., 2008; Ahmaruzzaman, 2010; Bhatnagar \& Sillanpää, 2010). In these works, results of the adsorption capacity of metallic species, by different kinds of residues, were presented. Previous studies, conducted in Brazil (with peel residues of coconuts, Eichornia crassipes and sugar cane bagasse, for removing iron from the water) showed promissory results. However, the authors reinforced the importance of further studies about this matter. Some coconut residues, such as the kernel, bunch, peels, cup flour, male flowers of coconut tree, peel ashes, have been studied as adsorbents for removing several pollutants from water, such as heavy metals and other toxic species (Bailey et al., 1999; Anirudhan \& Unnithan, 2007; Bhatnagar \& Sillanpäa, 2010). The authors point out the importance of such studies, essentially due to the low cost and high availability of these materials. However, in the extensive literature on the subject, there are few published papers about the correlations between the chemical functional groups present in natural fibers and their adsorption capacity of metallic ions (Garg et al., 2008).

Coconut, cocoa and eucalyptus can be found in some agricultural crops and in the most important planted forests in Brazil. The volume of waste generated by production and consumption of these crops is very high. A significant part of these residues is discarded into the environment. According to IBGE (2013), the Brazilian Institute of Geography and Statistics (Instituto Brasileiro de Geografia e Estatística), by LASP (Systematic Survey of Agricultural Production 2013), the coconut production in Brazil reached near to 2 million tons in 2013. The volume of residues generated in 2013 was approximately $970,000 \mathrm{~m}^{3}$ of coconut fiber.

Other important economic activity that produces a large volume of residues is the wood production. The eucalyptus wood is one of the most used, in Brazil, for the production of cellulose paper pulp. In 2013, Brazil produced 15.129 million tons of celulose (BRACELPA, 2014). According to Bragatto (2010) approximately $12 \%$ of timber required for the production of cellulose consists of bark residues. Thus, it is estimated that 3.6 million tons of bark residues were generated in Brazil in 2013.

The cocoa cultivation also has significant production in Brazil, especially in Bahia. However for cocoa crop mainly the seeds are availed, generating a large amount of residues. Brazilian production of cocoa beans is approximately 240 thousand tons, which represents about one million tons of peels (CEPLAC, 2013).

The possible use of agricultural and forestry residues as adsorbents of metals in waters must have, as a previous condition, the study of water-soluble substances and the determination of the adsorption capacity of metal ions. Moreover, it is very important to know about their chemical functional groups, present in the same, because it can conduce to explain the potential of the adsorption capacity. Thereby, the goal of this work is to study the possible use of peels of cocoa, coconut and eucalyptus for removing $\mathrm{Cd}^{+2}$ and $\mathrm{Cu}^{+2}$ ions, and determining the existing correlation between the adsorption capacity for these metallic species and the chemical functional groups present in the fibers.

\section{Material ANd Methods}

The samples of coconut peels (Cocos nucifera) were collected from the production fields located in the South of Bahia. The cocoa peels (Theobroma cacao) were collected from the fields of the Executive Committee for Planning of Cocoa Plantations - CEPLAC (Comissão Executiva de Planejamento da Lavoura Cacaueira), in Ilhéus, Bahia. The eucalyptus bark samples (hybrid of Eucalyptus grandis and Eucalytus urophylla) were collected from a cellulose industry called Veracel, in Eunápolis, Bahia.

The coconut, cocoa and eucalyptus samples were cut in pieces of approximately $2 \mathrm{~cm}$ and then dried (at $103 \pm 2$ ${ }^{\circ} \mathrm{C}$ ), with hot air, in an oven, during $48 \mathrm{~h}$. After drying, they were grounded in a mill of knives generating particles with granulometry between 1 and $2 \mathrm{~mm}$. The milled material was subjected to a soluble solid extraction in hot bath. $5 \mathrm{mg}$ of dried milled fiber of coconut, cocoa and eucalyptus bark were weighed and then placed in beakers of $250 \mathrm{~mL}$.

The aqueous extraction was performed by observing the proportion of 1 part by fiber weight per 7 parts by volume of distilled water. The beakers were covered and then taken to the waterbath for $30 \mathrm{~min}$ at a temperature of $90{ }^{\circ} \mathrm{C}$ for coconut peels and eucalyptus bark samples, and at $70^{\circ} \mathrm{C}$ for samples of cocoa peels. In every extraction, the distilled water was used as solvent, except for cocoa (ethanol 95\%). The extractions were made in triplicates. The extracts obtained were transferred to volumetric flasks of $250 \mathrm{~mL}$, and their volumes were completed with distilled water.

For the determination of total soluble solids (TSS), $5 \mathrm{~mL}$ bark extract were taken. Then, the extracts were transferred to a $50 \mathrm{~mL}$ test tube, previously weighed. The beakers, with the extracts, were taken to the hot air oven $\left(103+2{ }^{\circ} \mathrm{C}\right)$ 
during enough time for evaporating the liquid. After the total liquid evaporation, a new weighing was made, until achieving constant values.

The determination of reactive phenols was made by heating with reflux according to Luzardo (Luzardo et al., 2004). The reaction was performed with $50 \mathrm{~mL}$ bark extracts and then they were transferred to a $300 \mathrm{~mL}$ round-bottom flask. $10 \mathrm{~mL}$ of formaldehyde (37\%) and $5 \mathrm{~mL}$ of hydrochloric acid (38\%) were added. This flask, with a condenser, was heated, during $30 \mathrm{~min}$, since the beginning of the boiling. The precipitate obtained was filtered and transferred to a $50 \mathrm{~mL}$ beaker previously weighed, and then it was washed with distilled water. The complete water evaporation was performed by a hot air oven $(103+2$ $\left.{ }^{\circ} \mathrm{C}\right)$. After the total liquid evaporation, a new weighing was made, until achieving constant values for determinating the reactive phenols.

The IR spectra were obtained in four cases: natural fibers, lyophilized aqueous extracts of fibers, natural fibers washed and the commercial Mimosa tannin. To obtain the IR spectra of studied cases, $10 \mathrm{mg}$ of the powder (dry weight) was mixed with $\mathrm{KBr}(10 \% / 90 \% \mathrm{w} / \mathrm{w})$ and pressed, separately, on pellet sample, so that they could be analyzed by infrared spectroscopy using the spectrophotometer Perkin Elmer (the SPECTRUM 400 FT-IR/FT-NIR model). The spectra were plotted using the same scale on the transmittance axis for all cases.

Metal ion solutions (at concentration of $30 \mathrm{mg} \mathrm{L}^{-1}$ at $\mathrm{pH}$ 2.0 and $\mathrm{pH} 6.5$, for $\mathrm{Cd}^{+2}$, and $\mathrm{pH} 4.0$ for $\mathrm{Cu}^{+2}$ ) were prepared by diluting $1000 \mathrm{mg} \mathrm{L}^{-1}$ Merck stock solutions. The choice of $\mathrm{pH}$ values were based on results of previous studies (Ahmaruzzamans 2010; Palma et al., 2003). The selected pH values $(\mathrm{pH}=2, \mathrm{pH} 6.5$ for $\mathrm{Cd}$ and $\mathrm{Cu}=4)$ are in the range of neutral to acid $\mathrm{pH}$, given the interest in studying the potential for removing metals ions from wastewaters and mine acidic residual waters. The $\mathrm{pH}$ was adjusted with $\mathrm{NaOH}$ and $\mathrm{HNO}_{3}$ before the adsorption studies. Batch sorption experiments were conducted at room temperature $\left(25^{\circ} \mathrm{C}\right)$. The containers with $10 \mathrm{~mL}$ of solutions of $\mathrm{Cd}^{+2}$ and $\mathrm{Cu}^{+2}$, with peel powder (masses between 0.1 and $0.5 \mathrm{~g}$, dry weight), were stirred for $24 \mathrm{~h}$. After this step, three supernatant aliquots (of $1 \mathrm{~mL}$ each) were collected and then the solutions were diluted with $4 \mathrm{~mL}$ of $\mathrm{HNO}_{3} 0.1 \mathrm{~mol} \mathrm{~L}^{-1}$ solution. The resulting solutions were analysed by flame atomic absorption spectrometry.

A Buck Scientific 210VGP atomic absorption spectrometer, equipped with an air-acetylene flame and deuterium background corrector, was used for the metallic species quantification. Detection limits for cadmium and copper, from water samples, were 0.004 and $0.006 \mathrm{mg} \mathrm{L}^{-1}$ respectively. Metal adsorption was evaluated from the difference between the initial concentration of $\mathrm{Cd}^{+2}$ and $\mathrm{Cu}^{+2}$ and the final supernatant solution (Eq. 1 below).

$$
q=\frac{\left[M^{+2}\right]_{i}-\left[M^{+2}\right]_{f}}{m} V
$$

where:

$\mathrm{q} \quad$ - adsorption capacity, $\mathrm{mg} \mathrm{g}^{-1}$

$\left[\mathrm{M}^{+2}\right]_{\mathrm{i}}$ - concentration of ion, $\mathrm{mg} \mathrm{L}^{-1}$, in initial solution

$\left[\mathrm{M}^{+2}\right]_{\mathrm{f}}$ - concentration of ion, $\mathrm{mg} \mathrm{L}^{-1}$, in elution solution in equilibrium
$\mathrm{V} \quad$ - volume de solution used, $\mathrm{L}$

$\mathrm{m}$ - dried weight of the sorbent mass, $\mathrm{g}$

The results of the concentration of soluble solids and reactive phenols were analysed using Duncan's multiple range test and STATGRAPHICS Plus. The analysis of the bivariate correlation between adsorption capacity of metallic ions and the transmittance of chemical functional groups present in the fibers was performed with the Pearson correlation coefficient, using IBM SPSS Statistic v19 software.

\section{RESUlts AND Discussion}

This research aims to provide results that can help in the use of crop residues such as coconut, cocoa and eucalyptus as adsorbents of metals in natural water. When these fibers are used as adsorbents, it is important to determine the concentration and composition of soluble solids in order to prevent water contamination with these compounds.

The results of the concentration of soluble solids, extracted from the studied residues, have interesting levels to be marketed. This is valid when an appropriate proportion of reactive phenols are associated with condensed tannins. Significant differences were detected in the concentration of soluble solids extracted from the peels of the studied materials. According to the results of Duncan's Multiple Range Test, the yield of soluble solids and reactive phenols were significantly different for the studied peels, showing the highest value for coconut, followed by the eucalyptus and cocoa (Table 1). The yield of soluble solids obtained from the bark of eucalyptus was $12.6 \%$, which is close to those reported by Luzardo (Luzardo, 1989) for the soluble solids content (of 13.1\%) obtained from the Eucalyptus saligna bark. However, it is important to note that different eucalyptus species can show considerable differences in the content of reactive phenols. The yield of soluble solids obtained for coconut peels was lower than reported by Brígida \& Rosa (2003) probably due to climate and geographical influence.

The Duncan test results for reactive phenols present in the aqueous extract of the bark indicate that there is no significant difference between the eucalyptus and coconut extract, however, notable differences appear with cocoa extract. The results for reactive phenols of 3.6 and $4 \%$ from eucalyptus and coconut extracts, respectively, are constituted mainly by polyphenol compounds, like condensed tannin. These polyphenol compounds can react with an aldehyde with free hydrogen in the alpha position, such as formaldehyde (Luzardo, 1989; Luzardo et al., 2004), so they can be immobilized within the fiber itself. The cocoa peels extract presents only $0.3 \%$ of reactive phenols.

The results reported by Brígida \& Rosa (2003) show higher values for the yield of soluble solids from the coconut extract.

Table 1. Mean values of extracted soluble solids and reactive phenols (\% dry weight of the fiber)

\begin{tabular}{lccccc}
\hline \multirow{2}{*}{ Residues } & \multicolumn{2}{c}{ Soluble solids - \% } & & \multicolumn{2}{c}{ Reactive phenols - \% } \\
\cline { 2 - 3 } \cline { 5 - 6 } Cocoa peel & Mean & Stand. desv. & & Mean & Stand. desv \\
Eucaliptus bark & 8.76 & 0.25 & & 0.32 & 0.08 \\
Coconut peel & 12.68 & 0.62 & & 3.63 & 0.22 \\
\hline
\end{tabular}


The authors reported a yield of more than $70 \%$ of total soluble solids, and a condensed tannin concentration of $6.03 \%$, based on the Stiasny's Reaction. This result for condensed tannin is higher than one obtained in our study: 4.09\%. This difference may be related to several factors, age of the plant, the maturity of the coconut, among others.

The results obtained for the soluble solid content in the fibers indicate the need of an exhaustive washing process of the fibers prior to their use as adsorbent material.

The vegetable residues are mainly composed of lignin and cellulose. Other components are hemicelluloses, extractives, lipids, proteins, sugars, starches, water, hydrocarbons, and other inorganic compounds that contain a variety of functional groups which can participate in the joining process with metals. The cellulose is a glucose homopolymer with glycosidic bond in the fourth position, through intra and intermolecular hydrogen bonds. The hemicelluloses are heteropolymers mainly composed of xylose with glycosidic bond in the fourth position and other substances with acetyl and feruoil glicouronil groups. Lignin is a three-dimensional aromatic polymer, covalently attached to xylan, in hardwoods, and to Galactoglucomannan in softwoods (Garg et al., 2007). The functional groups present in biomass are molecules of acetyl, carbonyl, phenolic structures of polysaccharides, starch, sulfhydryl, carboxylic and esters (Gupta \& Imran, 2004).

The polyhydroxy phenols are composed of active chemical species of vegetable tannins in the adsorption process. The chemical activity of these species, with adjacent hydroxyl groups, contributes to the capture of cations, enabling to form chelates. The formation of complex compounds can also occur with the carbonyl or hydroxyl compound polyphenols (Oliveira et al., 2005).

The IR spectrum of the extracts and the Mimosa tannin (Figures 1, 2 and 3) showed certain coincidences in the bands from 704 to $778 \mathrm{~cm}^{-1}$. These coincidences are characteristic of mono and di-substituted benzenes corresponding to out of plane deformation in the case of aromatic compounds. The bands of $815-819 \mathrm{~cm}^{-1}$ are related to para-substituted benzene with C-H deformations out of the plane, except for 864-886 $\mathrm{cm}^{-1}$ bands of the cocoa and coconut extracts. These bands also appear in Mimosa tannin and they are corresponding to proanthocyanidins (flavonoids with two or three hydroxyl groups in the B ring), which are present in the condensed tannin extracts. They may also be present in the compounds of the complex oligomeric condensed tannins from the eucalyptus bark.

In $1029-1032 \mathrm{~cm}^{-1}, 1208-1256 \mathrm{~cm}^{-1}, 1338-1354 \mathrm{~cm}^{-1}$, 1403-1443 cm $\mathrm{cm}^{-1}, 1595-1610 \mathrm{~cm}^{-1}$ bands, coincidences were found in all three extracts; and also in Mimosa tannin, which corresponds to proantocyanidins (Vennat et al., 1987). In $1717-1719 \mathrm{~cm}^{-1}$ and $3255-3295 \mathrm{~cm}^{-1}$ bands, coincidences were also found in the three extracts. The first band is related to the carbonyl group, the second one shows the presence of hydroxyl groups in polyhydroxy phenols. It is worth to notice that the transmittances of the $1020-1034 \mathrm{~cm}^{-1}$ and 3282 $3341 \mathrm{~cm}^{-1}$ bands for the cocoa's peel extract is lower than for other extracts. This may be related to a low concentration of functional groups found in these regions of the IR spectrum.

The $1029-1032 \mathrm{~cm}^{-1}$ bands suggests the presence of axial deformation in the $\mathrm{CO}$ bonds of the heterocyclic ring present in the condensed tannins. The highest intensity band was found in cocoa extracts, followed by the eucalyptus and coconut ones. This behavior can be related to a large number of carbonyl groups $(\mathrm{C}=\mathrm{O}) 1208-1256 \mathrm{~cm}^{-1}$, typical for aryl-OH present in the eucalyptus extract, or aryl-O-CH2 present in the peel extract of coconut and cocoa. These groups are characteristic of phenols and carboxylic acids. The $1338-1354 \mathrm{~cm}^{-1}$ bands show a stretching of hydrogen-OH's bonds, characteristic of tannin compounds. The $1403-1443 \mathrm{~cm}^{-1}$ bands are associated with angular deformation of the bonds $\mathrm{C}=\mathrm{O}$ and $\mathrm{OH}$, which correspond to an axial deformation of the carboxylic acid. The presence of the $1595-1610 \mathrm{~cm}^{-1}$ bands indicates the existence of

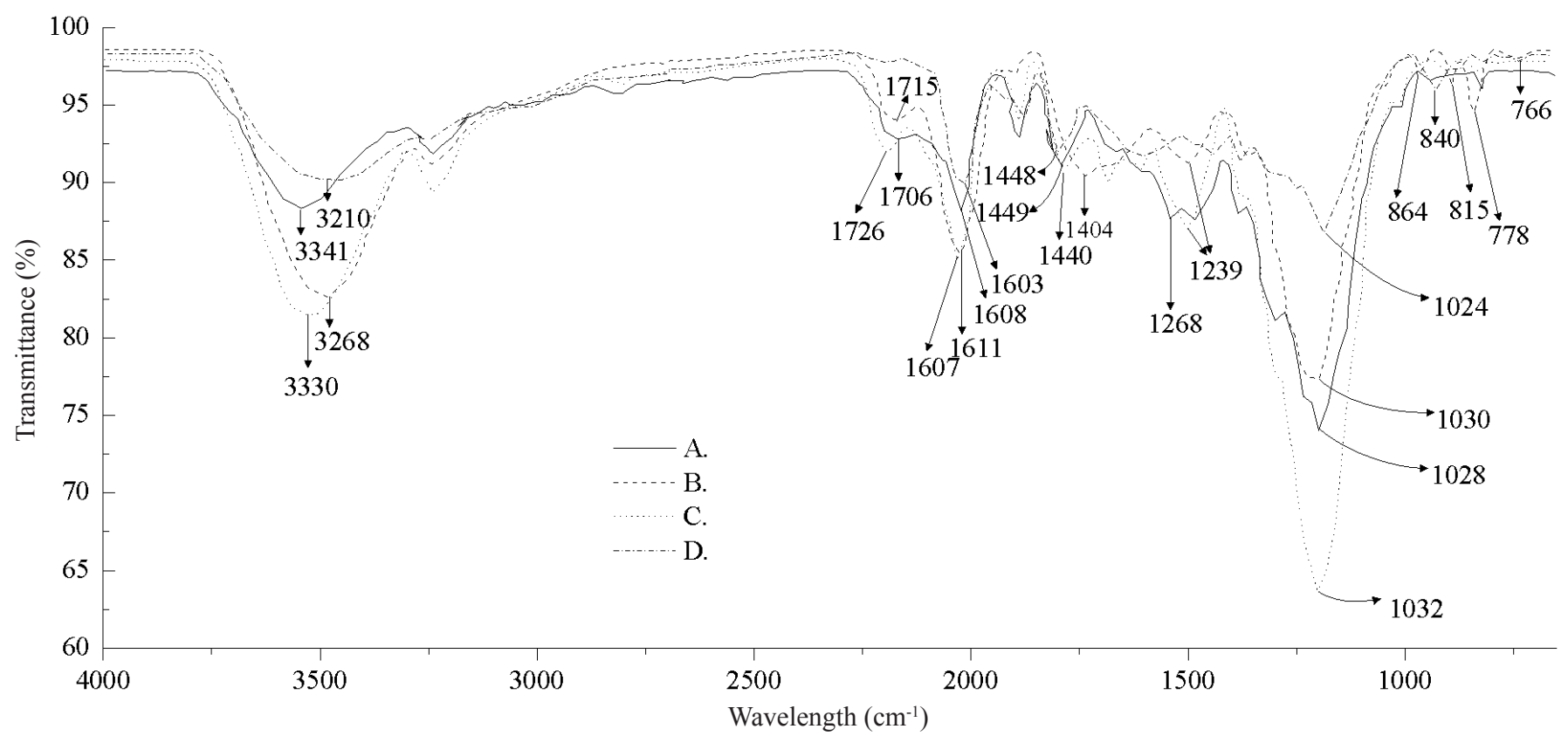

Figure 1. IR spectra of coconut peel with immobilized tannin without extraction (A), from aqueous extract of coconut peel (B), from coconut washed peel (C), and IR spectrum from tannic extrato (commercial) of Mimosa (D) 


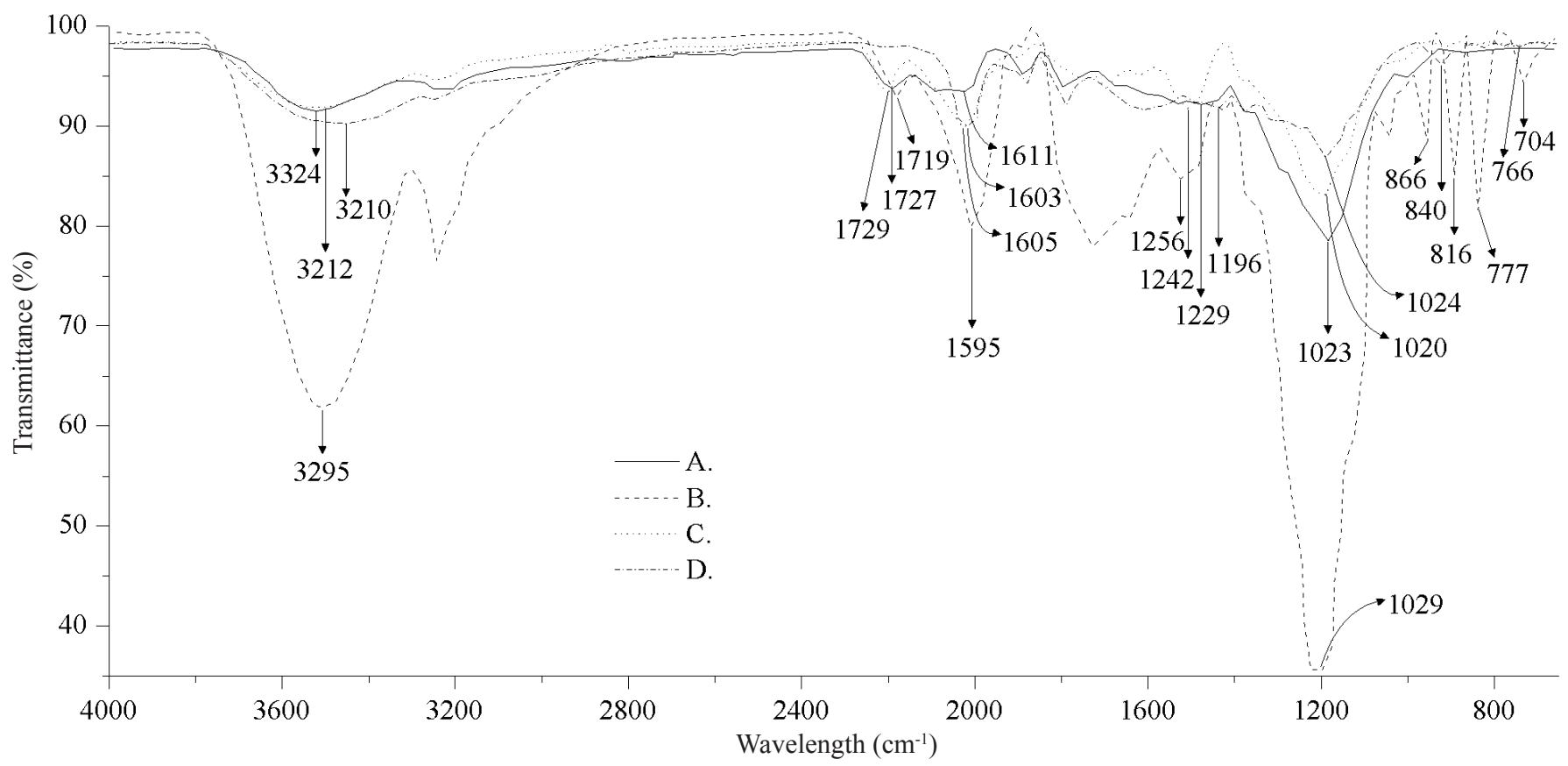

Figure 2. IR spectra of cocoa peel with immobilized tannins without extraction (A), from ethanol extract of cocoa peel (B), from washed cocoa peel (C), and IR spectrum from tannic extract (commercial) of Mimosa (D)

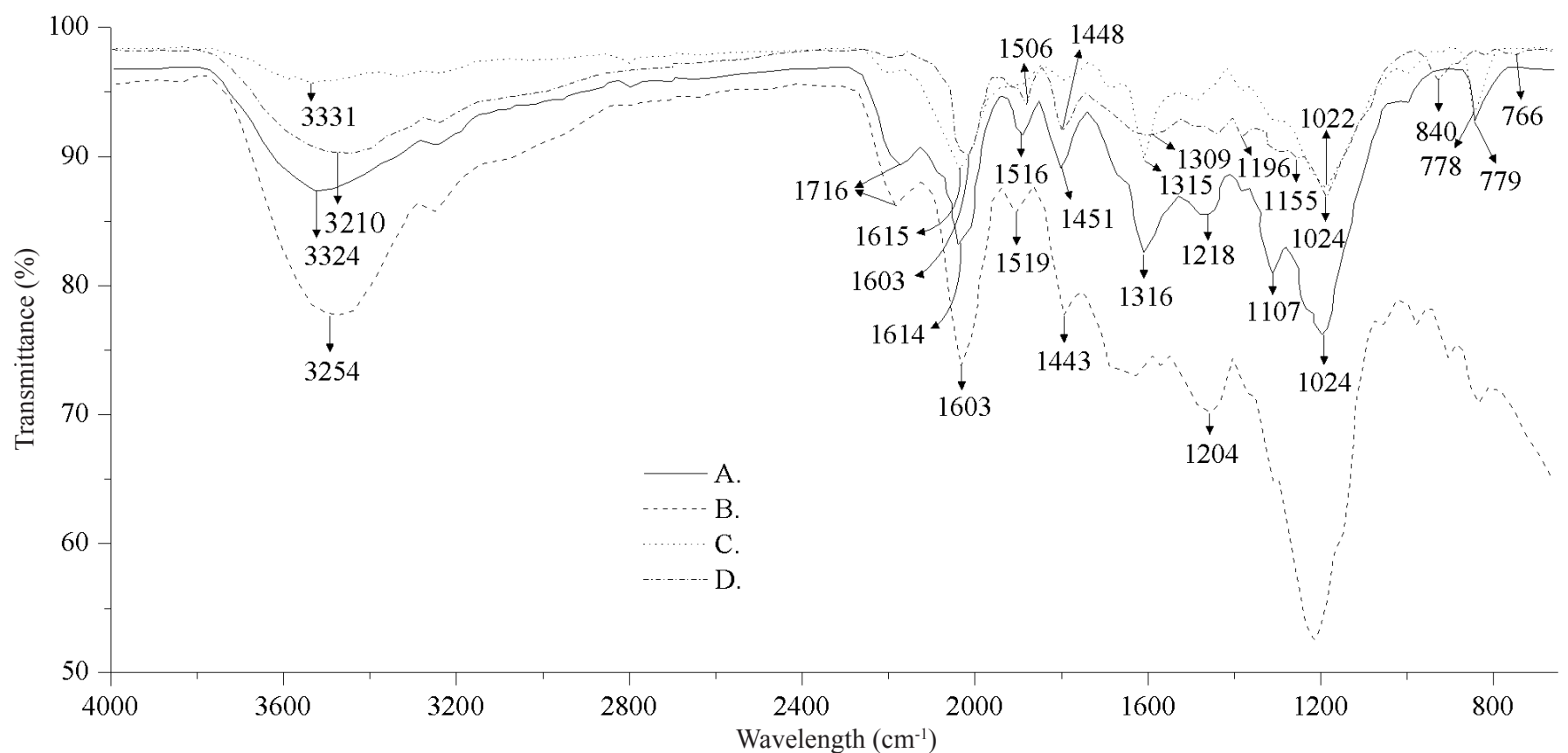

Figure 3. IR spectra of eucalyptus bark with immobilized tannins without extraction (A), from aqueous extract of eucalyptus peel (B), from washed eucalyptus peel (C) and IR spectrum from tannic extract (commercial) of Mimosa (D)

vibrations of conjugated CC bonds (aromatic nucleus), which are related to the phenyl pattern. These can also be associated with vibration $\mathrm{OH}$ out of plane.

The bands between 1717 and $1719 \mathrm{~cm}^{-1}$ correspond to the carbonyl group vibrations of carboxylic acids. Thus, the presence of carbonyl group was observed in all spectra, except in the Mimosa tannin one. These chemical functional groups are able to form complexes with metal ions in the plant residue structures. Therefore, according to our results, the cocoa and coconut fibers have potential for adsorption of metal ions. In this paper, the eucalyptus IR spectrum analysis confirm the reports by other authors (Luzardo, 1989; Miranda et al., 2000) that suggest their use as an adsorbent for removing toxic metals from wastewater. The behavior of $2926-2933 \mathrm{~cm}^{-1}$ bands was similar for the extracts from the peels of cocoa and coconut. In the spectrum of the eucalyptus bark extract, these bands were much less intense, probably associated with a lower intensity of vibrations in the bonds $\mathrm{C}-\mathrm{H}\left(\mathrm{C}_{\mathrm{sp} 3-} \mathrm{H}\right)$. Finally, the $3255-3295 \mathrm{~cm}^{-1}$ bands indicate the presence of vibrations in the $\mathrm{OH}$ and hydrogen bonds in polymers present in vegetable tannins.

By analyzing the infrared spectra (IR) from the studied peels (Figures 1 to 3 ), residues before and after aqueous extractions, many coincidences were found. This is explained first by considering that a certain content of soluble phenolic compounds remains in the cell walls of the fibers, and on the 
other hand, these spectra depict the "footprint" of functional groups of the fiber structural composition.

Results obtained from these IR spectra show remarkable coincidence in the presence of some functional groups reported by Garg et al. (2008) for sugarcane and bagasse fibers, and by Vieira et al. (2010) for the babassu coconut fibers. In this work, the peaks observed, about 3260, 2930, 1720, 1610 and $1030 \mathrm{~cm}^{-1}$, reveal a similar composition of functional groups detected for other vegetable fibers by the aforementioned authors. It confirms the presence of lignin, cellulose and hemicelluloses, as polyhydroxy phenolic compounds in the fibers' structures.

Table 2 summarizes the results of copper and cadmium adsorption capacities of the peels washed, and it shows the comparison with the results reported by other authors at different $\mathrm{pH}$ values. The adsorption capacity obtained shows "typical" values for this kind of material if compared with results reported by other authors (Palma et al., 2003; Singh et al., 2005; Verma et al., 2008; Pehlivan et al., 2009). The metal sorption depends on the type of shell and $\mathrm{pH}$ value. In all studied peels, the adsorption of $\mathrm{Cu}^{+2}$ was considerably smaller than for ions $\mathrm{Cd}^{+2}$. At low $\mathrm{pH}$ values, a low adsorption capacity was obtained, which can be related to the reduced access of the metal species to negatively charged binding sites of the adsorbents. Although the obtained adsorption capacity was not too high, low-cost process for the preparation of these sorbents is an advantage for practical use. It can avoid the need to regenerate the adsorbents in processes generally expensive, and so using them to produce fiber composites with cement as building material.

A $\mathrm{pH}$ influence was also obtained for $\mathrm{Cd}^{+2}$ adsorption, highest at $\mathrm{pH}$ 6.5. Usually, adsorption of metal ions by vegetable fibers occurs in materials containing tannins. It can be explained through the chelation of the metal ion with the adjacent hydroxyl groups of the phenolic molecules (Lima et al., 1998). These complexes become more stable at higher $\mathrm{pH}$ values due to deprotonation of the carboxyl groups, which favors the chelation process.

Aiming to find regularities in the relations between the adsorption capacities and functional groups present in the fibers, bivariate correlation analysis were performed by using the Pearson coefficient. The adsorption capacity of $\mathrm{Cd}^{+2}$ ions shows a significant correlation with IR bands with 0.01 probability of error. The intensity of the bands at 3280-3341 $\mathrm{cm}^{-1}$ is high. These adsorption bands correspond to $\mathrm{OH}$ functional groups. On the other hand, the 1196-1268 $\mathrm{cm}^{-1}$ bands are also important, particularly those corresponding to higher intensity between $1208-1256 \mathrm{~cm}^{-1}$. These bands are characteristic of aryl-OH eucalyptus fibers, or aryl-O- $\mathrm{CH}_{2}$ phenols and carboxylic acids in coconut shells and cocoa. A correlation between the increase of adsorption capacity and the increase of the intensity of those bands, for both $\mathrm{pH}$ conditions was observed. Recent studies (Zhong et al., 2012) have reported results related to the role of carboxylic groups, on the adsorption of metallic ions, that coincide with our results. In paper (Zhong et al., 2012) is reported that a higher carboxyl content increased the adsorption capacities of $\mathrm{Cd}^{+2}$, using a porous bioadsorbent from lignocellulosic biomass. The authors also show that the adsorption capacities of $\mathrm{Cd}^{+2}$ increased as the $\mathrm{pH}$ of metal ion solution grows.
Table 2. Comparison of adsorption capacity of $\mathrm{Cd}^{+2}$ and $\mathrm{Cu}^{+2}$ for various vegetable materials

\begin{tabular}{|c|c|c|c|}
\hline Material & $\mathrm{pH}$ & $\begin{array}{l}\text { Adsorption } \\
\text { capacity } \\
\left(\mathrm{mg} \mathrm{g}^{-1}\right)\end{array}$ & Reference \\
\hline \multicolumn{4}{|l|}{ Metal: Cd } \\
\hline Rice polish & 8.6 & 9.72 & Orhan \& Büyükgüngör (1993) \\
\hline V. spiralis & 6 & 2.62 & Verma et al. (2008) \\
\hline P. stratiotes & 6 & 2.13 & Verma et al. (2008) \\
\hline E. crassipes & 6 & 1.98 & Verma et al. (2008) \\
\hline Waste tea & ---- & 1.63 & Zhong et al. (2012) \\
\hline Exhausted cofee & ---- & 1.48 & Zhong et al. (2012) \\
\hline Walnut shell & ---- & 1.50 & Singh et al. (2005) \\
\hline Pinus radiata (MB) & 3 & $1.02^{\mathrm{a}}$ & Palma et al. (2003) \\
\hline Pinus radiata (MT) & 3 & $0.68^{\mathrm{a}}$ & Palma et al. (2003) \\
\hline Coconut fiber & ---- & $1.7-2.5$ & Souza et al. (2007) \\
\hline Moringa seeds & 5 & 0.02 & Gonçalves et al. (2013a) \\
\hline Crambe seeds & 5 & 0.037 & Gonçalves et al. (2013b) \\
\hline Eucalyptus bark & 2 & $0.49 \pm 0.2$ & This work \\
\hline Eucalyptus bark & 6.5 & $2.47 \pm 0.1$ & This work \\
\hline Cocoa & 2 & $0.27 \pm 0.01$ & This work \\
\hline Cocoa & 6.5 & $1.81 \pm 0.1$ & This work \\
\hline Coconut & 2 & $0.06 \pm 0.003$ & This work \\
\hline Coconut & 6.5 & $1.06 \pm 004$ & This work \\
\hline \multicolumn{4}{|l|}{ Metal: Cu } \\
\hline Barley Straw & ---- & 4.64 & Pehlivan et al. (2009) \\
\hline E. crassipes & 6 & 2.98 & Verma et al. (2008) \\
\hline V. spiralis & 6 & 2.95 & Verma et al. (2008) \\
\hline P. stratiotes & 6 & 2.77 & Verma et al. (2008) \\
\hline Pinus radiata (MB) & 3 & $1.50^{\mathrm{a}}$ & Palma et al. (2003) \\
\hline Pinus radiata (MT) & 3 & $1.43^{\mathrm{a}}$ & Palma et al. (2003) \\
\hline Coconut fiber & ---- & $1.1-2.04$ & Souza et al. (2007) \\
\hline Eucalyptus bark & 4 & $0.12 \pm 0.007$ & This work \\
\hline Cocoa & 4 & $0.02 \pm 0.001$ & This work \\
\hline Coconut & 4 & $0.16 \pm 0.01$ & This work \\
\hline
\end{tabular}

${ }^{a}$ Maximum capacity

In the case of $\mathrm{Cu}^{+2}$ ions, the adsorption capacity, in the washed peels, do not present a significant correlation with any specific bands. Meanwhile, at 1605 and $1318 \mathrm{~cm}^{-1}$, it was observed that the highest, intensities of the bands are associated to a lower adsorption capacity.

\section{Conclusions}

1. The possibility of use of cocoa, coconut and eucalyptus peels as adsorbent for removing $\mathrm{Cd}^{+2}$ and $\mathrm{Cu}^{+2}$ ions in water with a previous and exhaustive washing process of the fibers was demonstrated.

2. The potential use of these peels as adsorbent of $\mathrm{Cd}^{+2}$, as obtained in this work, is based on the presence of $\mathrm{OH}$ functional groups, such as aryl-OH, aryl-O- $\mathrm{CH}_{2}$ of phenol carboxylic acids, as well as carbonyl groups derived from carboxylic acid salts.

3. The correlation analyses between chemical functional groups and adsorption capacity can help to evaluate the potential use of these materials as adsorbents of metals in water.

\section{Literature Cited}

Ahmaruzzaman, M. A Review on the utilization of fly ash. Progress in Energy Combustion Science, v.36, p.327-363, 2010. http://dx.doi. org/10.1016/j.pecs.2009.11.003

Anirudhan, T. S.; Unnithan, M. R. Arsenic(V) removal from aqueous solutions using an anion exchanger derived from coconut coir pith and its recovery. Chemosphere, v.66, p.60-66, 2007. http://dx.doi. org/10.1016/j.chemosphere.2006.05.031 
Bailey, S. E.; Olin, T. J.; Bricka, M.; Adrian, D. D. A review of potentially low-cost sorbents for heavy metals. Water Research, v.33, p.24692479, 1999. http://dx.doi.org/10.1016/S0043-1354(98)00475-8

Bhatnagar, A.; Sillanpää, M. Utilization of agro-industrial and municipal waste materials as potential adsorbents for water treatment - a review. Chemical Engineering Journal, v.157, p.277-296, 2010. http://dx.doi.org/10.1016/j.cej.2010.01.007

BRACELPA - Associação Brasileira de Celulose e Papel. Conjuntura Bracelpa, 64, março 2014. p.5. <http://bracelpa.org.br/bra2/sites/ default/files/conjuntura/CB-064.pdf >. 11 Set. 2014.

Bragatto, J. Avaliação do potencial da casca de Eucalyptus spp. para a produção de bioetanol. Piracicaba: USP, 2010. 154p. Tese Doutorado

Brígida, A. I. S.; Rosa, M. F. Determinação do teor de taninos na casca de coco verde (Cocos nucifera). Interamerican Society for Tropical Horticulture, v.47, p.25-27, 2003.

CEPLAC - Comissão Executiva de Planejamento da Lavoura Cacaueira. Cacau - informações de mercado. Ano v, n.20, 2013.

Garg, U. K.; Garg, V. K.; Kaur, M. P.; Sud, D. J. Adsorption of Chromium from Aqueous Solution on Treated Sawdust. Journal of Hazardous Materials, v.140, p.60-68, 2007. http://dx.doi.org/10.1016/j. jhazmat.2006.06.056

Garg, U. K.; Kaur, M. P.; Garg, V. K.; Sud, D. J. Removal of Nickel (II) from aqueous solution by adsorption on agricultural waste biomass using a response surface methodological approach. Bioresource Technology, v.99, p.1325-1331, 2008. http://dx.doi.org/10.1016/j. biortech.2007.02.011

Gonçalves, A. C.; Mereghel, A. P.; Rubio, F.; Strey, L.; Dragunski, C.; Coelho, G. Applicability of Moringa oleifera Lam. Pies as an adsorbent for removal of heavy metals from waters. Revista Brasileira de Engenharia Agrícola e Ambiental, v.17, p.94-99, 2013a. http://dx.doi.org/10.1590/S1415-43662013000100013

Gonçalves, A .C.; Rubio, F.; Mereghel, A. P.; Coelho, G.; Dragunski, C.; Strey, L. The use of Cambre abyssinica seeds as adsorvent in the removal of metals from waters. Revista Brasileira de Engenharia Agrícola e Ambiental, v.17, p.301-311, 2013b. http://dx.doi. org/10.1590/S1415-43662013000300009

Gupta, V. K.; Imran, A. Removal of lead and chromium from wastewater using bagasse fly ash - a sugar industry waste. Advances in Colloid and Interface Science, v.271, p.321-328, 2004. http://dx.doi. org/10.1016/j.jcis.2003.11.007

IBGE - Instituto Brasileiro de Geografia e Estatística. Levantamento sistemático da produção agrícola. Rio de Janeiro: IBGE, 2013. v 26, p.1, p.43.

Lima, L.C.; Olivares, S.; Luzardo, F. H. M.; Torres, J.; Rosa, D. L.; Cepulveda, C. Use of immobilized Tannin adsorbent for removal of $\mathrm{Cr}(\mathrm{VI})$ from water. Journal of Radioanalytical and Nuclear Chemistry, v.231, p.3540, 1998. http://dx.doi.org/10.1007/BF02388001

Luzardo, F. H. M. Obtención, caracterización y uso industrial de taninos vegetales contenidos en la corteza de cinco especies forestales que crecen en Cuba. La Habana: Centro Nacional de Investigaciones Científicas, 1989. 207p. Tesis Doctorado

Luzardo, F. H. M.; Hernández, J. T.; Lima, L. C.; Mayworm, M. A. S.; Arruda, J. D. T.; Cestari, C. Método químico para la inmovilización de taninos en la corteza para la remoción de metales pesados en aguas. Oficina Cubana de la Propiedad Industrial. Certificado de patente n.22929, 2004. 8p. <http://www.ocpi.cu/patentes/textos/ t01-0100.pdf>. 11 Set 2014.
Miranda, C. E. S.; Olivares, S.; Reis, B. F.; Luzardo, F. H. M. Online preconcentration employing a tannin resin for copper determination in plant material and food stuff by atomic absorption spectrometry. Journal of the Brazilian Chemical Society, v.11, p.44-49, 2000. http://dx.doi.org/10.1590/S010350532000000100009

Mohan, D.; Pittman, C. U. Jr. Arsenic removal from water/wastewater using adsorbents - a critical review. Journal of Hazardous Materials, v.142, p.1-53, 2007. http://dx.doi.org/10.1016/j. jhazmat.2007.01.006

Oliveira, E. A.; Montanher, S. F.; Andrade, A. D.; Nobrega, J. A.; Rollemberg, M. C. Equilibrium studies for the sorption of the chromium and nickel from aqueous solutions using raw rice bran. Process Biochemistry, v.40, p.3485-3490, 2005. http://dx.doi. org/10.1016/j.procbio.2005.02.026

Orhan, Y.; Büyükgüngör, $H$. The removal of heavy metals by using agricultural waste. Water Science and Technology, v.28, p.247255, 1993.

Palma, G.; Freer, J.; Baeza, J. Removal of metal ions by modified Pinus Radiata bark and Tannins from water solutions. Water Research, v.37, p.4974-4980, 2003. http://dx.doi.org/10.1016/j. watres.2003.08.008

Pehlivan, E.; Altun, T.; Parlayici, S. Utilization of barley straws as biosorbents for $\mathrm{Cu}^{2+}$ and $\mathrm{Pb}^{2+}$ ions. Journal of Hazardous Materials, v.164, p.982-986, 2009. http://dx.doi.org/10.1016/j. jhazmat.2008.08.115

Singh, K. K.; Rastogi, R.; Hasan, S. H. Removal of hazard cadmium from waste water using agricultural waste rush. Polish Journal of Hazardous Materials, v.A121, p.51-58, 2005. http://dx.doi. org/10.1016/j.jhazmat.2004.11.002

Souza, S. W.; Moreira, S. A.; Oliveira, A. G.; Cavalcante, S. M.; Nascimento, R. F.; Rosa, M. F. Uso da casca de coco verde como adsorvente na remoção de metais tóxicos. Química Nova, v.30, p.1153-1157, 2007. http://dx.doi.org/10.1590/S010040422007000500019

Sud, D.; Mahajan, G.; Kaur, M. P. Agricultural waste material as potential adsorbent for sequestering heavy metal ions from aqueous solutions - A review. Bioresource Technology, v.99, p.6017-6027, 2008. http://dx.doi.org/10.1016/j.biortech.2007.11.064

Vennat, B.; Pourrot, A.; Texier, O.; Pourrot, H. Proanthocyanidins from the roots of Fragaria Vesca. Phytochemistry, v.26, p.261-263, 1987. http://dx.doi.org/10.1016/S0031-9422(00)81524-1

Verma, V. K.; Tewari, S.; Rai, J. P. N. Ion exchange during heavy metal bio-sorption from aqueous solution by dried biomass of macrophytes. Bioresource Technology, v.99, p.1932-1938, 2008. http://dx.doi.org/10.1016/j.biortech.2007.03.042

Vieira, A. P.; Santana, S. A. A.; Bezerra, C. W. B.; Silva, H. A. S.; Melo, J. C. P.; Silva Filho, E. C.; Airoldi, C. Copper sorption from aqueous solutions and sugar cane spirits by chemically modify babassu coconut (Orbignya speciosa) mesocarp. Chemical Engineering Journal, v.161, p.99-105, 2010. http://dx.doi.org/10.1016/j. cej.2010.04.036

Zhong, L. X.; Peng, X. W.; Yang, D.; Sun, R. C. Adsorption of heavy metals by a porous bioadsorbent from lignocellulosic biomass reconstructed in an ionic liquid. Journal of Agricultural and Food Chemistry, v.60, p.5621-5628, 2012. http://dx.doi.org/10.1021/ jf301182x 